\title{
Histopathological effects of waterborne silver nanoparticles and silver salt on the gills and liver of goldfish Carassius auratus
}

\author{
S. Abarghoei ${ }^{1}$ A. Hedayati ${ }^{1}$ R. Ghorbani ${ }^{1} \cdot$ H. K. Miandareh ${ }^{1} \cdot$ T. Bagheri $^{1}$
}

Received: 6 May 2015/Revised: 28 December 2015/Accepted: 22 February 2016/Published online: 15 March 2016

(C) Islamic Azad University (IAU) 2016

\begin{abstract}
This study aimed to compare histopathological effect of waterborne silver nanoparticles and silver salt $\left(\mathrm{AgNO}_{3}\right)$ on the gills and liver of Carassius auratus. Therefore, one hundred and five live specimens of goldfish were obtained and treated in five aquariums with $0,0.01$, 0.025, 0.05, and $0.1 \mathrm{ppm}$ of $\mathrm{AgNO}_{3}$ and 0, 0.1, 0.5, 1, and $5 \mathrm{ppm}$ of Ag nanoparticles (mean particle size of $5 \mathrm{~nm}$ ). Fish were sampled after 14 days of exposure. Results showed that the kinds of pathologies observed with Ag NPs were broadly of the same type as $\mathrm{AgNO}_{3}$ including hyperplasia, edema and lifting of the gill epithelium, and lamellar fusion of the gills, and hemosiderosis, hemorrhage, hydropic swelling, and pyknotic nuclei of the liver. Overall, the data showed that although $\mathrm{Ag}$ nanoparticles and $\mathrm{AgNO}_{3}$ pathology were similar, but $\mathrm{Ag}$ nanoparticles caused less injury than $\mathrm{AgNO}_{3}$ in the gills and liver of goldfish. Therefore, it is more proper to use nanoform of Ag in industrials.
\end{abstract}

Keywords Silver nanoparticles · Gill pathology $\cdot$ Liver injury $\cdot$ Silver toxicity $\cdot$ Fish

A. Hedayati

hedayati@gau.ac.ir

1 Department of Fisheries, Gorgan University of Agricultural Sciences and Natural Resources, Goran, Iran

\section{Introduction}

Ecotoxicology is the study of the impact of environmental contaminant on ecosystems. Understanding the effect of toxicants on fish supports the larger ecotoxicological goal of comprehending the action of ecotoxicans on fish population (Bols et al. 2001). Ecotoxicans are a diverse group of substrate that have two general properties: they are depleted into the environment, and they have the potential to impact on ecosystem and animals at relatively low concentration (Connell et al. 1999). Heavy metals are the major chemical substrates that contaminate the ecosystems (Bols et al. 2001). Silver, as ionic $\mathrm{Ag}^{+}$, is one of the most toxic metals known to aquatic organisms in laboratory testing and is of concern in various aquatic ecosystems because of the severity of silver contamination in the water column, sediments, and biota (Eisler 1996). Silver was used as halide in the manufacture of photographic imaging materials, jewelry, coins, indelible inks, eating utensils and used as silver salt in caustics, germicides, antiseptics, and astringents (Klaassen et al. 1986). In addition, relatively recently, a new form of $\mathrm{Ag}$ metal has been engineered comprising of $\mathrm{Ag}$ nanoparticles (Ag NPs) that can have novel and size-related physicochemical properties differing significantly from those from larger particles (Fabrega et al. 2011). Ag NPs are widely used in medicine, cosmetics, environmental remediation or electronic devices (Fabrega et al. 2011) and have distinctive physicochemical properties, including surfaceenhanced Raman scattering, high electrical and thermal conductivity, chemical stability, catalytic activity, and nonlinear optical behavior (Capek 2004; Frattini et al. 2005). 
Silver toxicity and the pathological effects of waterborne silver are well known in freshwater fish species (Janes and Playle 1995; Wood et al. 1996; Zhou et al. 2005). The gill is considered the main route for waterborne Ag uptake and destruction of tissue by reaching the branchial epithelial cells via the $\mathrm{Na}^{+}$channel and coupling to the proton ATPase in the apical membrane of the gills, and blocking the $\mathrm{Na}^{+} \mathrm{K}^{+}$ATPase which affects ionoregulation of $\mathrm{Na}^{+} \mathrm{Cl}^{-}$ions across the gills (Bury and Wood 1999). Ag can also cause tissue damage and accumulate in the liver tissue affecting the ability of fish to cope with low oxygen levels and inducing oxidative stress (Bilberg et al. 2010a, b; Scown et al. 2010).

Many researchers studied the ecotoxicity of nanomaterials to aquatic ecosystems (Moore 2006; Handy et al. 2008; Klaine et al. 2008; Kahru and Savolainen 2010; Handy et al. 2011, Khabbazi et al. 2014a, b); however, the environmental impacts of Ag NPs are, as yet, unknown (Fabrega et al. 2011), and data on internal organ pathologies from Ag NPs in Carassius auratus (goldfish) are generally lacking. In addition, the relative hazard of pathology from nanoforms of $\mathrm{Ag}$ compared to traditional metal salts is unknown. Therefore, the aim of this study was to determine the effects of dissolved $\mathrm{Ag}$ and $\mathrm{Ag} \mathrm{NPs}$ on the gills and liver of goldfish following waterborne exposure to these materials. Another goal of current study was to compare and contrast the effects of Ag metal with Ag NPs, to identify any nano-specific pathologies. This research was done in Aquaculture laboratory of Gorgan University of Agricultural Sciences and Natural Resources in the autumn of 2013.

\section{Materials and methods}

One hundred and five live specimens of goldfish were obtained. Samples weighted $56.33 \pm 12.05 \mathrm{~g}$. They were acclimatized randomly in 100-L aquariums for 1 week. Ag nanocolloid was prepared from Nonaka Company, Iran (Antimicrobial Product 2 brand, $4000 \mathrm{ppm}$ nanosilver concentration, mean particle size of $5 \mathrm{~nm}$ ). In addition, silver nitrate $\left(\mathrm{AgNO}_{3}\right)$ with $5000 \mathrm{ppm}$ concentration was purchased from Merck Company (Merck Company, Frankfurter, Germany).

Five aquariums were treated with $0.01,0.025,0.05$, $0.1 \mathrm{ppm}$ of $\mathrm{AgNO}_{3}$ with one control group (no Ag NPs) and $0,0.1,0.5,1,5 \mathrm{ppm}$ of $\mathrm{Ag}$ NPs. No feeding occurred during the test to avoid confounding the exposure with potential food particles in the water. There were no significant differences between aquariums in water quality, and the following were constant: $\mathrm{pH}$ : $7.56 \pm 0.45$ (TS1); temperature: $19 \pm 1{ }^{\circ} \mathrm{C}$; hardness: $293 \pm 2.35 \mathrm{ppm}$; and dissolved oxygen: $8.80 \pm 0.06 \mathrm{mg}$ $\mathrm{L}^{-1}$ (DO-5510). $80 \%$ of water was changed every $12 \mathrm{~h}$ with re-dosing after each change, and the photoperiod was 12-h light and 12-h dark.

Fish were sampled from each of the triplicate tanks from each treatment after 14 days of exposure for histopathological studies. Histological examinations were performed as described in Bucke (1982). Fish were anaesthetized with $200 \mathrm{ppm}$ eugenol concentration in 5-L tanks, and tissues were collected in the following order: the second gill arch was taken from gills, and the hind part of liver was taken by abdominal dissection. Collected tissues were fixed in formalin solution 1-10, and dehydration with ethanol $96 \%$, clearing with xylenol,

Table 1 C. auratus biometric results in $\mathrm{AgNO}_{3}$ test

\begin{tabular}{llllll}
\hline Factors & Control & $0.1 \mathrm{ppm}$ concentration & 0.25 ppm concentration & 0.5 ppm concentration & 1 ppm concentration \\
\hline Total length $(\mathrm{cm})$ & $16.33 \pm 0.57^{\mathrm{a}}$ & $15.00 \pm 1.32^{\mathrm{a}}$ & $14.67 \pm 2.75^{\mathrm{a}}$ & $13.83 \pm 1.60^{\mathrm{a}}$ & $14.83 \pm 0.28^{\mathrm{a}}$ \\
Total weight $(\mathrm{g})$ & $61.66 \pm 14.57^{\mathrm{b}}$ & $54.33 \pm 13.31^{\mathrm{b}}$ & $44.67 \pm 16.16^{\mathrm{b}}$ & $45.33 \pm 12.89^{\mathrm{b}}$ & $41.00 \pm 5.29^{\mathrm{b}}$ \\
\hline
\end{tabular}

Data were represented by mean \pm standard deviation. Identical letters indicate no significant difference (ANOVA, $P<0.05$ )

Table 2 C. auratus biometric results in nanosilver test

\begin{tabular}{llllll}
\hline Factors & Control & 5 ppm concentration & 10 ppm concentration & 20 ppm concentration & 30 ppm concentration \\
\hline Total length $(\mathrm{cm})$ & $16.33 \pm 0.57^{\mathrm{a}}$ & $14.90 \pm 1.93^{\mathrm{a}}$ & $15.83 \pm 0.76^{\mathrm{a}}$ & $15.66 \pm 0.28^{\mathrm{a}}$ & $16.16 \pm 0.76^{\mathrm{a}}$ \\
Total weight $(\mathrm{g})$ & $61.66 \pm 14.57^{\mathrm{b}}$ & $45.66 \pm 14.15^{\mathrm{b}}$ & $56 \pm 14.73^{\mathrm{b}}$ & $56.66 \pm 10.01^{\mathrm{b}}$ & $62.66 \pm 3.51^{\mathrm{b}}$ \\
\hline
\end{tabular}

Data were represented by mean \pm standard deviation. Identical letters indicate no significant difference (ANOVA, $P<0.05$ ) 

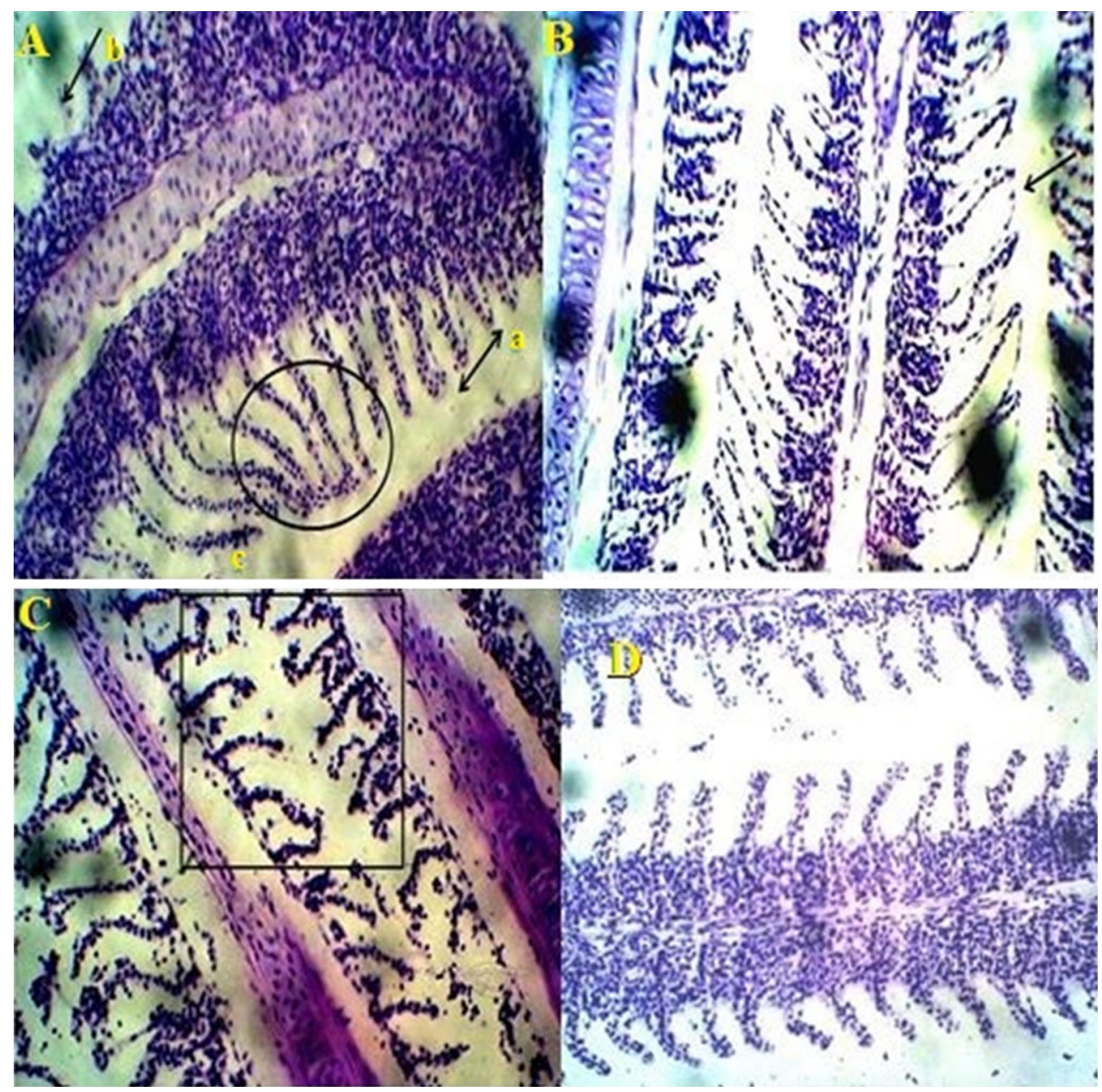

Fig. 1 Microphotographs of gill histopathological changes by $\mathrm{AgNO}_{3}$ or $\mathrm{Ag} \mathrm{NPs} \mathrm{in} \mathrm{C.} \mathrm{auratus.} \mathrm{A} \mathrm{secondary} \mathrm{lamellae} \mathrm{shrinking} \mathrm{(a),} \mathrm{secondary}$ lamellae destruction $(b)$, and lamellar fusion $(c)$, B edema, $\mathbf{C}$ secondary lamellae Clubbing, $\mathbf{D}$ normal gill. All pictures are magnified $\times 40$

Table 3 Index and scores for the $C$. auratus gills exposed to $\mathrm{Ag} \mathrm{NPs}$ and $\mathrm{AgNO}_{3}$ sublethal concentrations

\begin{tabular}{|c|c|c|c|c|c|c|}
\hline \multirow[t]{2}{*}{ Treatment } & \multirow[t]{2}{*}{ Concentration } & \multicolumn{4}{|l|}{ Lesions } & \multirow[t]{2}{*}{ Hyperplasia } \\
\hline & & Secondary lamellae shrinking & Secondary lamellae destruction & Lamellar fusion & Epithelial lifting & \\
\hline \multirow[t]{5}{*}{$\mathrm{AgNO}_{3}$} & 0 & - & - & - & - & - \\
\hline & 0.01 & - & + & + & + & - \\
\hline & 0.025 & + & ++ & ++ & +++ & ++ \\
\hline & 0.05 & ++ & ++ & +++ & ++ & ++++ \\
\hline & 0.1 & ++++ & ++++ & ++++ & +++ & ++++ \\
\hline \multirow[t]{5}{*}{ Ag NPs } & 0 & - & - & - & - & - \\
\hline & 0.1 & + & + & - & ++ & - \\
\hline & 0.5 & - & + & ++ & ++ & ++ \\
\hline & 1 & ++ & ++ & + & +++ & ++++ \\
\hline & 5 & + & ++ & ++ & +++ & +++ \\
\hline
\end{tabular}

$(-)$ no observed lesions, $(+)$ 1-3 observed lesions, $(++)$ 3-5 observed lesions, $(+++)$ 5-11 observed lesions, $(++++) 11$ and more observed lesions 
impregnation with paraffin, embedding, sectioning, mounting, and staining with $\mathrm{H} \& \mathrm{E}$ were performed, respectively (Khabbazi et al. 2014b). All of these steps were conducted by tissue processor under defined program (Tissue processor, Triangle biomedical sciences USA). Histopathological changes induced by treatments in the tissues were photographed using Nikon photomicroscope. Quantitative histological measurements were taken in several tissues of gills and livers.

Data were analyzed by using SPSS 20 one-way analysis of variance (ANOVA). The least squares difference (LSD) post hoc test $(P<0.05)$ was used to identify
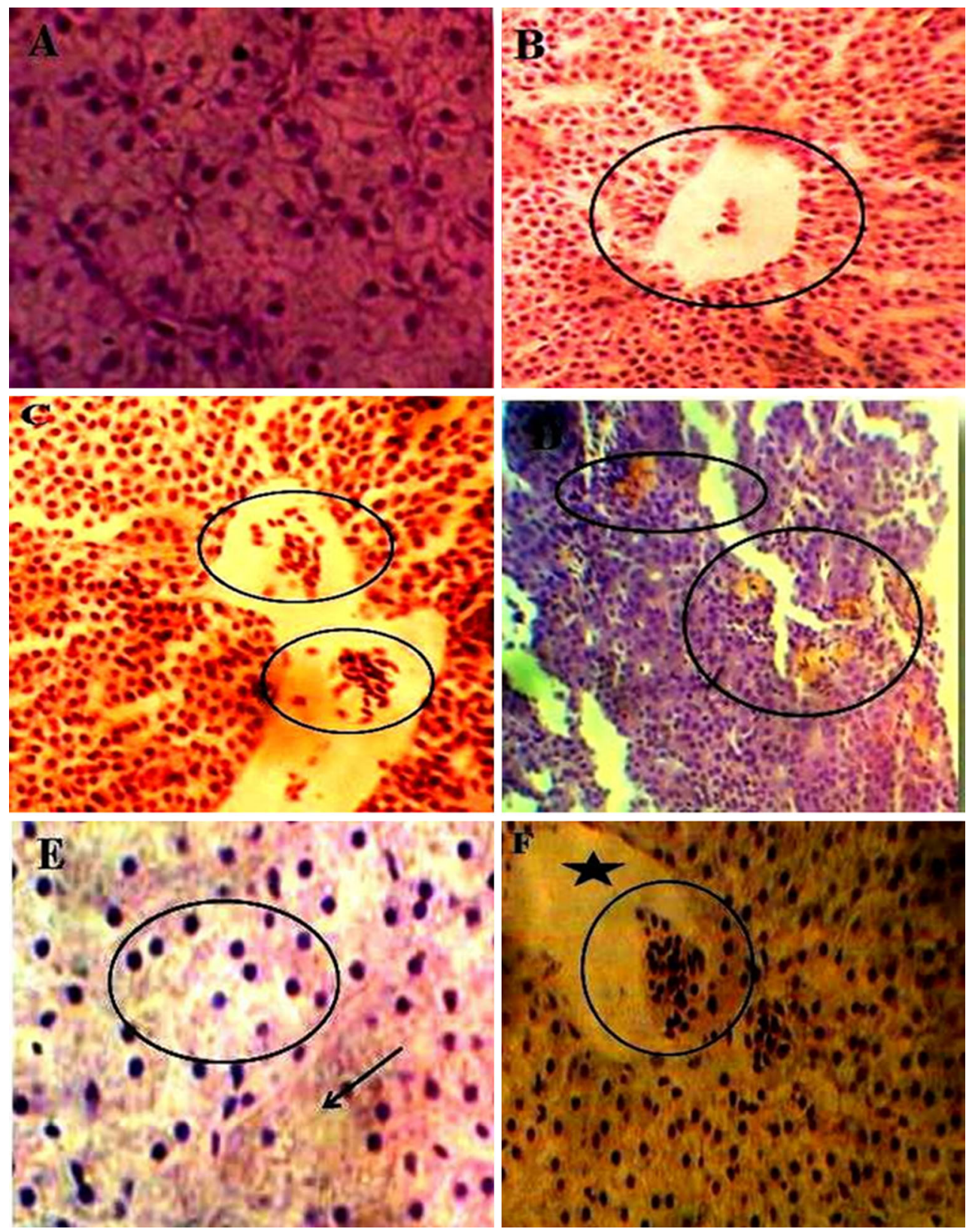

Fig. 2 Microphotographs of liver histopathological changes by $\mathrm{AgNO}_{3}$ or $\mathrm{Ag} \mathrm{NPs}$ in C. auratus. A Normal liver, $\mathbf{B}$ hydropic swelling, $\mathbf{C}$ hemorrhage, $\mathbf{D}$ hemosiderin, $\mathbf{E}$ necrosis, and $\mathbf{F}$ pyknotic nuclei and hydropic swelling. All pictures are magnified $\times 40$ 
treatment effects at the end of the experiment (day 14). To illustrate the intensity of tissue damage by following the procedure, scoring system was applied as described analogously in Mitchell et al. (2012): (-) was used for no observed injuries, $(+)$ for $1-3,(++)$ for $3-5,(+++)$ for 5-11, and $(++++)$ for 11 and more observed injuries in samples.

\section{Results and discussion}

Tables 1 and 2 show mean total weight and length of fishes in treatments after experiment dubitation. No significant differences were observed in total length and weight of fish in all treatments with control group $(P>0.05)$.

\section{Histological observation on the gill}

Gill morphology of goldfish was normal in all the unexposed control groups. Exposure to waterborne Ag nitrate and Ag NPs caused various gill injuries after 14 days. Histological examination of gills showed areas of hyperplasia, edema and lifting of the gill epithelium, and lamellar fusion (Fig. 1). Exposure to Ag NP treatment produced similar gill pathologies to those observed with $\mathrm{AgNO}_{3}$ (Fig. 1), but the extent of these injuries was less severe in the fish exposed to Ag NPs in comparison with $\mathrm{AgNO}_{3}$ (Table 3).

\section{Histological observation on the liver}

No injuries were observed in control group. Histopathological examination showed different types of lesions such as hemosiderosis, hemorrhage, hydropic swelling, and pyknotic nuclei (Fig. 2). Results showed that Ag NPs caused similar injuries in comparison with $\mathrm{AgNO}_{3}$, but the severities of injuries were less in Ag NP groups (Table 4).

This study showed the effects of dissolved Ag compared to Ag NPs on the liver and gills of goldfish. Overall, the results indicated that dissolved $\mathrm{Ag}$ and $\mathrm{Ag}$ NPs cause similar types of injuries in these two organs. After 14 days, these injuries were greater with $\mathrm{AgNO}_{3}$ than $\mathrm{Ag}$ NPs. Results showed that the $\mathrm{AgNO}_{3}$ concentration had greater injuries than Ag NPs in goldfish gills and livers especially in higher concentrations. Bioaccumulation is the major factor in metal toxicities. There is some evidence that waterborne exposure to metal NPs may result in particle accumulation in or on the epithelial cells (e.g., Ti NPs, Moger et al. 2008), but NP accumulation is less than metal salt and the metal salt is more bioavailable and/or bioreactive than the nanoform (e.g., $\mathrm{CuSO}_{4}$, Al-Bairuty et al. 2013).

Gills are the first organ that encountered to toxicants. Mallatt (1985) stated that gill lesions can be divided into two groups, one that reflects the direct effect of toxicants and another corresponding to defense responses of fishes.

Table 4 Index and scores for the $C$. auratus gills exposed to $\mathrm{Ag} \mathrm{NPs}$ and $\mathrm{AgNO}_{3}$ sublethal concentrations

\begin{tabular}{|c|c|c|c|c|c|c|}
\hline \multirow[t]{2}{*}{ Treatment } & \multirow[t]{2}{*}{ Concentration } & \multicolumn{4}{|l|}{ Lesions } & \multirow[t]{2}{*}{ Liver cell destruction } \\
\hline & & Hydropic swelling & Hemorrhage & Hemosiderin & Necrosis & \\
\hline \multirow[t]{5}{*}{$\mathrm{AgNO}_{3}$} & 0 & - & - & - & - & - \\
\hline & 0.01 & + & + & - & + & + \\
\hline & 0.025 & ++ & + & - & + & ++ \\
\hline & 0.05 & ++ & ++ & + & +++ & ++++ \\
\hline & 0.1 & +++ & +++ & ++ & ++++ & ++++ \\
\hline \multirow[t]{5}{*}{ Ag NPs } & 0 & - & - & - & - & - \\
\hline & 0.1 & - & + & - & - & - \\
\hline & 0.5 & - & + & - & + & + \\
\hline & 1 & + & ++++ & - & ++ & + \\
\hline & 5 & + & ++ & - & +++ & ++ \\
\hline
\end{tabular}

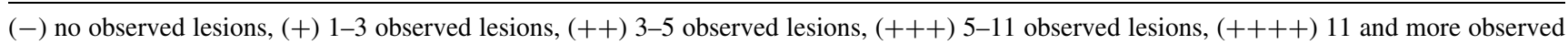
lesions 
Several studies have been demonstrated on laboratory experiments, to determine the toxicity of heavy metals, organochlorine pesticides, and petroleum hydrocarbon products to fish gill (Al-Attar 2007; Garcia-Santos et al. 2007; Patnaik et al. 2011; Santos et al. 2011; Hesni et al. 2011; Moitra et al. 2012; Ullah and Zorriehzahra 2015). Hyperplasia and lamellar fusion known to be induced by many gill tissue irritants; however, focal points of cellular hypertrophy and necrosis followed by epithelial rupture reflect the direct deleterious effects of heavy metals in fish gills (Mazon et al. 2002). In addition, similar gill injuries by titanium $\left(\mathrm{TiO}_{2}\right)$ in Cyprinus carpio (Hao et al. 2009) and $\mathrm{Cu}$ (Al-Bairuty et al. 2013) were reported. Further, the types of gill injuries by silver evaluated in this study also have been reported by other researchers (Griffitt et al. 2009; Bilberg et al. 2010a, b).

$\mathrm{Ag}$ accumulates in large amounts in the kidney and liver and acts as a very potent inducer of metallothionein synthesis (Coleman and Cearlry 1974; Wood et al. 1999). The rate of accumulation of heavy metals is positively correlated to their concentrations (Portman 1972). Results showed that level of injuries increased with $\mathrm{Ag}$ concentrations. This suggests that higher metal concentrations increase the rate of accumulation of $\mathrm{Ag}$ in liver. The types of injuries reported here (Fig. 2) for $\mathrm{AgNO}_{3}$ and Ag NPs were coincided with other reports about histological changes in the hepatic tissue of fish (Lee et al. 2007; Yeo and Kang 2008; Mishra and Mohanty 2009). Some studies also revealed a link between hepatic lesions and the concentration of hemosiderin (Khan 1998 and 1999). Hemosiderin was not observed in Ag NP treatment and observed only in higher $\mathrm{AgNO}_{3}$ concentrations (Table 4). This suggests that Ag NPs accumulate less than Ag salt in liver.

\section{Conclusion}

In conclusion, this study has demonstrated that Ag NPs and $\mathrm{AgNO}_{3}$ cause similar lesions in gills and liver of goldfish, but the severity of $\mathrm{Ag} \mathrm{NPs}$ is less than $\mathrm{AgNO}_{3}$. It is well known that organ pathology is not necessary for determining the adverse effect of $\mathrm{Ag}$, and accumulation in all of the internal organs should be considered. For this purpose, further studies should be focused on heavy metal accumulation in fish organs.

Acknowledgments This study was funded by student grants from the Gorgan University of Agricultural Sciences and Natural Resources, Goran, Iran, Department of fishery. The grant number was 9121033181.

\section{References}

Al-Attar AM (2007) The influences of nickel exposure on selected physiological parameters and gill structure in the teleost fish Oreochromis niloticus. J Biol Sci 7:77-85

Al-Bairuty GA, Shaw BJ, Handy RD, Henry TB (2013) Histopathological effects of waterborne copper nanoparticles and copper sulphate on the organs of rainbow trout (Oncorhynchus mykiss). Aquat Toxicol 126:104-115

Bilberg K, Malte H, Wang T, Baatrup E (2010a) Silver nanoparticles and silver nitrate cause respiratory stress in Eurasian perch (Perca fluviatilis). Aquat Toxicol 96:159-165

Bilberg K, Malte H, Wang T, Baatrup E (2010b) Silver nanoparticles and silver nitrate cause respiratory stress in eurasian perch (Perca fluviatilis). Aquat Toxicol 96:159-165

Bols NC, Brubacher JL, Ganassin RC, Lee LEG (2001) Ecotoxicology and innate immunity fish. Dev Comp Immunol 25(8-9):853-873

Bucke D (1982) Some histological techniques applicable to fish tissues. In: Mawdesley-Thomas LE (ed) Diseases of fish. Symposium of zoology society, London, 10, vol 30. Academic Press, New York, p 153 
Bury NR, Wood CM (1999) Mechanism of branchial apical silver uptake by rainbow trout is via the proton-coupled $\mathrm{Na}^{+}$channel. Am J Physiol Regul Integr Comp Physiol 277:R1385-R1391

Capek I (2004) Preparation of metal nanoparticles in water-in-oil (w/ o) microemulsions. Adv Colloid Interface Sci 110:49-74

Coleman RL, Cearlry JE (1974) Silver toxicity and accumulation in largemouth bass and bluegill. Bull Environ Contam Toxicol 12(1):53-61

Connell D, Lam P, Richardson B, Wu R (1999) Introduction to ecotoxicology. Blackwell Science Ltd, Oxford

Eisler R (1996) Silver hazards to fish, wildlife, and invertebrates: a synoptic review. U.S. Department of the Interior, National Biological Service. Report 32; Biological Report 32. 44 p

Fabrega J, Luoma SN, Tyler CR, Galloway TS, Lead JR (2011) Silver nanoparticles: behaviour and effects in the aquatic environment. Environ Int 37:517-531

Frattini A, Pellegri N, Nicastro D, Sanctis OD (2005) Effect of amine groups in the synthesis of Ag nanoparticles using aminosilanes. Mater Chem Phys 94:148-152

Garcia-Santos S, Monteiro M, Carrola J, Fontainhas-Fernandes A (2007) Histopathological lesions of tilapia Oreochromis niloticus gills caused by cadmium. Arq Bras Med Vet Zoo 59:376-381

Griffitt RJ, Hyndman K, Denslow ND, Barber DS (2009) Comparison of molecular and histological changes in zebrafish gills exposed to metallic nanoparticles. Toxicol Sci 107:404-415

Handy RD, von der Kammer F, Lead JR, Hassellöv M, Owen R, Crane M (2008) The ecotoxicology and chemistry of manufactured nanoparticles. Ecotoxicology 17:287-314

Handy RD, Al-Bairuty G, Al-Jubory A, Ramsden CS, Boyle D, Shaw BJ, Henry TB (2011) Effects of manufactured nanomaterials on fishes: a target organ and body systems physiology approach. J Fish Biol 79:821-853

Hao L, Wang Z, Xing B (2009) Effect of sub-acute exposure to TiO2 nanoparticles on oxidative stress and histopathological changes in juvenile carp (Cyprinus carpio). J Environ Sci 21:1459-1466

Hesni MA, Savari A, Sohrab AD, Mortazavi MS (2011) Gill histopathological changes in milkfish (Chanos chanos) exposed to acute toxicity of diesel oil. World Appl Sci J 14:1487-1492

Janes N, Playle RC (1995) Modeling silver-binding to gills of rainbow trout (Onchorrynchus mykiss). Environ Toxicol Chem 14:1847-1858

Kahru A, Savolainen K (2010) Potential hazard of nanoparticles: from properties to biological and environmental effects. Toxicology 269:89-91

Khabbazi M, Harsij M, Hedayati SAA, Gerami MH, Ghafari-Farsani H (2014a) Histopathology of rainbow trout gills after exposure to copper. Iran J Ichthyol 1(3):191-196

Khabbazi M, Harsij M, Hedayati SAA, Gholipoor H, Gerami MH, Ghafari Farsani H (2014b) Effect of $\mathrm{CuO}$ nanoparticles on some hematological indices of rainbow trout oncorhynchus mykiss and their potential toxicity. Nanomed J 2(1):67-73

Khan RA (1998) Influence of petroleum at a refinery terminal on feral winter flounder. Pleuronectes timer iccmus. Bull. Environ. Contain. Toxicol. 61:770-777
Klaassen CD, Amdur MO, Doull J (eds) (1986) Casarett and Doull's toxicology. The basic science of poisons, 3rd edn. Macmillan, New York

Klaine SJ, Alvarez PJJ, Batley GE, Fernandes TF, Handy RD, Lyon DY, Mahendra S, McLaughlin MJ, Lead JR (2008) Nanomaterials in the environment behavior, fate, bioavailability, and effects. Environ Toxicol Chem 27(1825): 1851

Lee KJ, Nallathamby PD, Browning LM, Osgood CJ, Xu XHN (2007) In vivo imaging of transport and biocompatibility of single Silver Nanoparticles in early development of zebrafish embryos. ACS Nano 1(2):133-143

Mallatt J (1985) Fish gill structural changes induced by toxicants and other irritants: a statistical review. Can J Fish Aquat Sci 42:630-648

Mazon AF, Cerqueira CCC, Fernandes MN (2002) Gill cellular changes induced by copper exposure in the South American tropical freshwater fish Prochilodus scrofa. Environ Res Sect A 88:52-63

Mishra AK, Mohanty B (2009) Chronic exposure to sublethal hexavalent chromium affects organ histopathology and serum cortisol profile of a teleost, Channa punctatus (Bloch). Sci Total Environ 407:5031-5038

Mitchell SO, Baxter EJ, Holland C, Rodger HD (2012) Development of a novel histopathological gill scoring protocol for assessment of gill health during a longitudinal study in marine-farmed Atlantic salmon (Salmo salar). Aquacult Int 20:813-825

Moger J, Johnston BD, Tyler CR (2008) Imaging metal oxide nanoparticles in biological structures with CARS microscopy. Opt Express 16:3408-3419

Moitra S, Bhattacharjee R, Sen NS (2012) Histopathological changes in the gills of air breathing teleost Clarias batrachus Linn. exposed to endosulfan. Asian J Exp Sci 26:23-26

Moore MN (2006) Do nanoparticles present ecotoxicological risks for the health of the aquatic environment? Environ Int 32:967-976

Patnaik BB, Howrelia HJ, Mathews T, Selvanayagam M (2011) Histopathology of gill, liver, muscle and brain of Cyprinus carpio communis L. exposed to sublethal concentration of lead and cadmium. Afr J Biotechnol 10:12218-12223

Portman JE (1972) The levels of certain metals from coastal waters around England and Wales. J Aquacult 1:91-96

Santos DCM, Matta SLP, Oliveira JA, Santos JAD (2011) Histological alterations in gills of Astyanax aff. bimaculatus caused by acute exposition to zinc. Exp Toxicol Pathol. doi:10.1016/j.etp. 2011.03.007

Scown T, Santos E, Johnston B, Gaiser B, Baalousha M, Mitov S, Lead JR, Stone V, Fernandes TF, Jepson M, van Aerel R, Tylor CR (2010) Effects of aqueous exposure to silver nanoparticles of different sizes in rainbow trout. Toxicol Sci 115:521-534

Ullah S, Zorriehzahra MJ (2015) Ecotoxicology: a review of pesticides induced toxicity in fish. Adv Anim Vet Sci 3(1):40-57

Wood CM, Hogstrand C, Galvez F, Munger RS (1996) The physiology of waterborne silver toxicity in freshwater rainbow trout (Oncorhynchus mykiss) 1 . The effects of ionic $\mathrm{Ag}^{+}$. Aquat Toxicol 35:93 
Wood CM, Playle RC, Hogstrand C (1999). Physiology and modeling of mechanisms of silver uptake and toxicity in fish. Environ Toxicol Chem 18(1):71-83

Yeo M-K, Kang M (2008) Effects of nanometer sized silver materials on biological toxicity during zebrafish embryogenesis. Bull Korean Chem Soc 29(6):1179-1184
Zhou B, Nichols J, Playle RC, Wood CM (2005) An in vitro biotic ligand model (BLM) for silver binding to cultured gill epithelia of freshwater rainbow trout (Oncorhynchus mykiss). Toxicol Appl Pharmacol 202:25 